Цица 3. Бацић

Универзитет у Београду

Филолошки факултет
UDC: 371.3::811.163.41'35]:004.738.5

DOI: 10.18485/dh.2015.2.ch12

\title{
ДРУШТВЕНЕ МРЕЖЕ У НАСТАВИ СРПСКОГ ЈЕЗИКА У ОБЛАСТИ ПРАВОПИСА
}

\section{Сажетак}

У овом раду бавићемо се могућностима употребе друштвених мрежа у настави Српског језика и то у наставној области Правопис. Улога друштвених мрежа, пре свега Фејсбука, у свакодневном животу ученика је веома велика. Ученици већ у четвртом разреду основне школе имају своје сопствене профиле на Фејсбуку, који се махом користе за забаву, игру и комуникацију са вршњацима. Могућности које ова друштвена мрежа нуди су бескрајне и могу се успешно применити у наставном процесу, при чему би ученици, како на часу, тако и у виду домаћих задатака, користили Фејсбук у образовне сврхе. Дидактичко-методичким приступом, који подразумева одабир градива, алата и поступака, дозволићемо ученицима да ресурсе дигиталне хуманистике искористе у циљу ефикаснијег писменог, али и усменог изражавања, критичког и креативног мишљења, при чему смо у условима сеоске школе ученицима омогућили да позитивним коришћењем друштвене мреже развијају писану културу, овладавају правописним законитостима нашег језика и уједно смо надоместили недостатак наставних средстава. Уз интердисциплинарни рад и корелацију са другим наставним предметима, у наставни процес су укључене демонстративне методе, а ученицима је омогућено да решавају правописне проблеме, комуницирају, спроводе своја истраживања, управљају временом, раде индивидуално или тимски, толеришу разноликости и развијају самопоуздање. Овакав начин учења доприноси модернизацији наставе и у предности је у односу на тзв. традиционалну наставу.

У раду ћемо представити и неколико примера из властите праксе, који су се показали успешним и применљивим у свакодневној наставној пракси и који укључују примену постојећих, лако доступних ресурса дигиталне хуманистике.

Кључне речи: друштвене мреже, правопис, Фејсбук, усмено и писмено изражавање, наставна средства, модерна настава, корелација 


\section{1. Увод}

Правописна проблематика је једна од најчешћих тема која подстиче интересовањечитаве јавности, предметје стручних разматрања, али и лаичких реаговања. Ова проблематика најчешће се доводи у везу са образовањем и наставом српског језика јер резултати правописних истраживања показују да „правописно знање наших ученика и студената није добро па би ваљало уложити додатног напора у образовном процесу, како би се поправило“ (Брборић, 2011: 101). С друге стране све чешће се могу чути мишљења да је за такво стање одговоран језик нових медија, при чему су критичком преиспитивању нарочито изложене друштвене мреже. До недавно готово да и није било истраживања и дискусија о утицајима ових медија на образовање, тек у последњих неколико година светска истраживања потврђују да друштвене мреже у учионицама чине наставу ефикаснијом (Кејси \& Еванс, 2011). Добробити коришћења друштвених сајтова у настави односе на све актере образовно-васпитног процеса (Јунко, Мерсон, \& Салтер, 2010; Јунко Хаибергер \& Локен, 2011). Осим позитивних аспеката, срећемо се и са упозорењима њиховог коришћења (Аипеј, Ердоган \& Созер, 2007). Резултати истраживања у нашој земљи углавном се односе на утицај енглеског језика на језик и писмо нових медија (Прћић, 2005; Влајковић, 2010; Богданић, 2013), као и на манипулативне могућности друштвених сервиса (Дурбаба, 2009).

Друштвене мреже као „комуникационе структуре које су, заправо, обрасци контаката који настају услед протока порука међу учесницима у комуникацији кроз време и простор“ (Кастелс, 2014: 42), представљају један од највећих изазова за савремену наставу. Будући да је примарна сврха друштвених мрежа комуникација, сарадња и дружење, атрактивне су за тинејџере, те је и број ученика корисника друштвених мрежа све већи. Убрзани развој савремене информационе и комуникационе технологије доноси нове могућности њихове примене у настави. Велико интересовање ученика, као и чињеница да млади воле умрежавање, потврђују тезу да школе морају да се фокусирају на образовне вредности коришћења друштвених мрежа, а све у циљу остваривања што бољих постигнућа. Фејсбук, Твитер, 
ЛинкедИн, Гугл +, Пинтерест, данас уживају огромну популарност јер омогућавају различите начине употребе, изграђују односе и везе у различитим контекстима, бољу комуникацију и сарадњу, контролу информација, бесплатне су и привлаче све већи број најмлађих корисника, често млађих и од прописаног минимума од 13 година, те као такве могу имати примену и у настави.

Главна претпоставка овог рада је да Фејсбук може бити ефикасно употребљен у основној школи у настави Српског језика, нарочито у области Правописа из више разлога:

1. Фејсбук је најпопуларнија мрежа на свету, данас има преко 1 490000000 корисника, пре свега због своје једноставне употребе јер не захтева посебне вештине и обуке, регистрација је лака, довољан је само имејл и лозинка.

2. Активни корисници овог сервиса нису само ученици, већ и њихови наставници што може представљати посебан изазов за наставнике да успоставе бољу комуникацију са својим ученицима, да размењују информације, постављају мултимедијалне садржаје и алате који могу бити и едукативни и сигурни, стварајући на тај начин плодно тло за учење.

3. Чињеница да је Фејсбук део свакодневнице наших ученика, може бити моћан ресурс за остваривање образовно-васпитних циљева и задатака. Дигитални урођеници ${ }^{1}$ „који практично одрастају уз нове комуникационе технологије, 'растежу` своје друштвене односе кроз реални и виртуелни простор, а да нису ни свесни тога. За њих практично нема разлике између реалности и виртуалности, и једино им је важно да се интеракција перманентно одвија“ ( Петровић, 2013: 122). Ово практично значи да су млади нон-стоп на интернету и да се комуникација одвија у писаном облику.

С појавом нових медија распространило се мишљење да Фејсбук дирекно утиче на лошу писменост ученика и на правописно знање ученика. Будући да се као главно обележје ове мреже исти-

1 Овај појам се односи на младе који су практично одрасле уз рачунаре, интернет, мобилне телефоне, друштвене мреже итд, а „називом дигитални урођеници дочарана је разлика нових генерација од претходних генерација по томе што они размишљају и обрађују информације на другачији начин од својих претходника. Насупрот дигиталним урођеницима налазе се дигитални имигранти, а то су сви они који користе технологије, али зато што нису 'срасли' са њима, никада неће моћи користити као што то чине дигитални урођеници" (Петровић, 2013: 122). 
че комуникација без физичког присуства, омогућена технички преко тастатуре, потпуно је очекивано да ће оваква комуникација имати утицаја и на употребу језика и писма. На питање колико друштвене мреже, пре свега Фејсбук, заиста утичу на правописно (не)знање наших ученика, односно у којој мери су у сагласности прописана правописна норма и правопис који је заиста у употреби, није могуће одговорити јер не постоје конкретна истраживања која би дала доказане одговоре. Сврха овог рада, дакле, није процена нивоа правописног знања ученика, већ указивање на занимљиве могућности којима наставник у основној школи може да обогати часове предвиђене за увежбавање или утврђивање правописног градива, а што би могло да допринесе бољем писменом изражавању ученика. Ми ћемо у овом раду феномену „друштвена мрежа“ приступити као једном од највећих изазова за савремену, модерну наставу.

\section{2. Правопис и Фејсбук у настави}

Правопис (ортографија) је јединствен систем који регулише правилно писање, упућује на јасна правила којих се треба увек придржавати при писању па да текст буде правописно исправан.

Оспособљавање ученика да се правилно писмено изражавају је најважнији задатак наставе српског језика, стога су и садржаји у вези са правописом значајни не само за наставу српског језика, већ и за све друге школске предмете, али и за различите ваншколске активности. Од ученика се очекује да се и у свим животним ситуацијама правилно писмено изражавају, у складу с правописном нормом, да користе савремени књижевни језик и код куће, и у школи, и на фејсбуку нпр. Савремена настава српског језика мора да развија смисао и способност да се ученици правилно, течно, економично и уверљиво усмено и писмено изражавају, богатећи речник, језички и стилски израз. То је дуготрајан процес који подразумева увежбавање, учвршћивање вештина до те мере, да би се стекла вештина писања по аутоматизму. Дакле, да би стечена знања могла да прерасту у умења и навике, неопходно је редовно спроводити правописне и стилске вежбе. Методичари саветују да се у 
току усвајања правописних правила користе што разноврсније методе, облици рада и видови вежбања. „Практично могућности и комбинације су неисцрпне, условљене су конкретним наставним тренутком и имају један једини коначни циљ да се ученик оспособи да у писању правилно употреби одређено правило“ (Вучковић, 1993:198). Такође, наставницима је сугерисано да им увежбавање правописних правила мора бити стална радна обавеза при чему је неопходно да се свакодневно истичу правила нашег правописа без обзира да ли су „програмски захтев у том разреду или су усвајани у неком од претходних разреда“ (Исто).

Наставним плановима и програмима је предвиђено да наставници своје ученике у процесу описмењавања упућују на животне ситуације, при чему ће на примерима из своје околине ученик моћи да утврђује правописна правила тако што уочава исправно написане примере или да исправља своје или туђе грешке. У том смислу Фејсбук може бити моћни образовни алат за увежбавање и обнављање обрађеног градива низом активности индивидуално или кроз сарадњу са другима, при чему ученици могу да комбинују писани текст, видео, звук, фотографију, слику, апликацију, анимацију и друге садржаје. Правилним поступањем Фејсбук би у настави правописа олакшао практичну примену наученог, на забавни начин омогућио да се прошири речник, стимулисао вештине критичког размишљања ученика, самопроцену, креативно размишљање кроз коришћење дигиталних извора. Полазећи од чињенице да „наставу правописа није могуће преносити предавањем, већ изношењем правила с мноштвом примера и активним учешћем ученика“ (Брборић, 2011: 109), Фејсбук би на тај начин постао идеално наставно средство под условом да су примери правилно одабрани. Данашњи ученици су активни корисници и добри познаваоци овог сервиса, само их треба неприметно укључити у образовање, мотивисати и упознати са сајтовима који доприносе бољем писменом изражавању.

\section{3. Услови за квалитетну примену Фејсбука у настави правописа}

Како би садашње генерације боље разумеле значај правилног писменог изражавања, неопходана је нова концепција наста- 
ве и образовања усмерена на развијање ученичких компетенција и оспособљавање за целоживотно учење, а на наставнику је да усмерава, прати и подржава своје ученике. То практично значи да је глави предуслов за квалитетну примену Фејсбука у настави спремност и компетенције наставника да буде водич у процесу учења чије су технике и стратегије усмерене на ефикасније учење правописних садржаја, при чему повезује задатке учења са интересовањима и потребама ученика, инсистира на доследној практичној примени наученог, труди се да учење учини забавнијим кроз вршњачко учење, активну наставу, мултимедијалну стимулацију, користећи притом ону исту технологију коју користи његов ученик.

Важан предуслов за примену Фејсбука у настави је да се постојећа техника користи на адекватан начин. ${ }^{2}$ Чињеница је да савремена технологија може у потпуности да одговори захтевима модерне наставе, али то не значи Фејсбук треба користити увек и неконтролисано. Часови у којима је присутна модерна технологија осмишљавају се како би се обогатила настава тиме што се ученици ангажују на иновативне начине. Ученици модерног доба не прихватају да „буду подучавани“, желе да буду уважени у процесу учења, очекују отворенију комуникацију и двосмерну сарадњу, како са наставницима тако и са другим ученицима, али интеракција треба да буде смислена, а настава у којој је заступљена модерна технологија мора бити добро организована, што подразумева правилно одабрану методологију и одговарајући дидактички материјал.

\section{1. Поступци примене Фејсбука у настави правописа}

Примена Фејсбука у настави правописа одликује се новим дидактичко-методичким приступом, при чему се нова технологија уводи у наставу пре свега ради ефикасније примене и увежбавања наученог градива. Овакав тип наставног часа је условљен две-

2 Пројектом Министарства за телекомуникације и информационо друштво Републике Србије под називом „Дигитална школа“ 2010. године око 3000 основних школа опремљено је најсавременијом рачунарском опремом. Дигиталним кабинетима омогућено је ученицима из наше земље да имају исте интерактивне могућности као и њихови вршњаци из Европске уније. 
ма чињеницама, прво, поштујући законску регулативу о условима отварања Фејсбук профил налога оваквом наставом у основној школи могу бити обухваћени само ученици седмог и осмог разреда, и друго, готово сви водећи правописни садржаји су до осмог разреда већ обрађени и у седмом и осмом разреду се обнављају. Да би оваква настава дала добре резултате, неопходно је да буде брижљиво организована, што значи да наставник пре реализације наставе мора да предузме низ корака и активности које се односе на одабир циљне групе, планирање активности, стратегију и евалуацију.

За примену Фејсбука у образовне сврхе није довољно само да наставник има вољу и жељу да модернизује наставу. Неопходна је сагласност родитеља, врло је важно да родитеље обавестимо шта планирамо да урадимо и које ћемо алате користити у учионици како бисмо им предочили све предности укључења деце у овакву наставу. Неопходна је спремност и мотивисаност ученика да свој фејсбук профил користе за учење. Анкетирањем ученика могуће је испитати њихову спремност и ставове о учењу на друштвеним мрежама, као и податке о томе коју друштвену мрежу користе, колико времена дневно проводе на мрежи, као и који су разлози коришћења (Прилог 1). ${ }^{3}$ Већина ученика Фејсбук користи за забаву, али ће радо користи-

За потребе планирања наставних активности које подразумевају употребу Фејсбука у настави правописа, извршено је анкетирање ученика с циљем да се испита спремност да уче путм друштвених мрежа. Узорак испитаника се састојао од 68 ученика седмог и осмог разреда сеоске основне школе у околини Крушевца. Анкета се састојала од пет питања. Будући да је циљ нашег рада могућност коришћења Фејсбука у настави, из тог разлога нећемо се детаљније бавити анализом добијених резултата. У кратким цртама осврнућемо се на податке који су релевантни за овај рад. Дакле, од 68 анкетираних ученика 66 ученика (97. 06 \%) има свој профил на Фејсбуку и то је уједно и мрежа коју користе, само 2 ученика (2. 94\%) нема свој профил ни на једној друштвеној мрежи, али користе профил брата, односно сестре. Занимљиво је да (иако нисмо тражили те податке) 12 ученика има и по неколико профила на овој мрежи. Ово истраживање је показало да ученици много времена проводе на мрежи: 11 ученика (16, 18\%) тврди је увек на мрежи, 8 (11, 76 \%) проводи у просеку по 4 сата дневно, 29 (42, 65 \%) је на Фејсбуку по два сата дневно, 18 (26, 47 \%) проводи на мрежи по сат времена сваког дана, а само 2 (2, 94 \%) ученика су изјавила да нису активна баш сваки дан. Када су у питању разлози коришћења друштвених мрежа, сви анкетирани ученици се дописују, прате статусе својих пријатеља, постављају своје статусе и фотографије, а 47 ученика $(69,12 \%)$ поред ових активности, игра игрице. На питање да ли сматрају да се Фејсбук може користити и у образовне 
ти ову мрежу за учење ако им се претходно објасни шта се то од њих очекује.

Други корак је одабир начина рада. Фејсбук је друштвена мрежа која нуди три модела креирања заједништва: отварање профил налога, странице или групе. Најподеснији модел је формирање групе чији ће чланови бити ученици једног одељења или разреда, односно окружење које је идентично оном у класичној настави с том разликом што су окупљени око одређеног образовног програма. У нашем случају група се формира само за потребе наставе правописа, при чему сви чланови добијају своја задужења и радне задатке. Наставник добија улогу више тиме што постаје и администратор групе, што практично значи да ради исто што и у традиционалној настави, с тим што као администратор прати и контролише све активности на групи, може да учлани или ишчлани ученика, да угаси групу, има веће могућности да користи постојеће алате, да одреди ниво приватности, односно да креира групу отвореног или затвореног типа. Наставник ће се радије определити за другу могућност како би информације размењивали искључиво чланови групе. Администратор може одредити још неку особу из групе да уређује групу или да постане администратор. Ученике можемо додатно мотивисати ако им објаснимо да чланови који се истичу својим радом могу бити унапређени и заједно са наставником уређивати групу. У новоформираној заједници могуда комуницирају сви ученици међусобно или са наставником, а додатна предност је што сви чланови добијају информације о дешавањима на групи чак и када Фејсбук користе за неке друге активности. Веома је важно да наставник води рачуна како се рад на групи одвија. Поред класичног примера где наставник поставља садржаје, ученици могу и сами да креирају и постављају своје радове.

Сама структура Фејсбука омогућава ученицима низ активности, које се најчешће одвијају на зиду. Постављени статуси су доступни

сврхе, већина је одговорила негативо, али да би то волели (60, $28 \%$ ), не зна $32,35 \%$ ученика, док 7, 37 \% ученика сматра да је учење путем друштвених мрежа могуће. Одговори који су добијени на последње питање су потпуно неочекивани јер је међу анкетираним ученицима највише било оних ученика са којима се већ примењивао неки вид учења путем Фејсбука. Но, оно што је наша анкета показала је да су ученици за које планирамо учење правописних садржаја, активни корисници Фејсбука и да су спремни да време које проводе на овом сервису искористе и за учење. 
свим члановима, могу се коментарисати, даље делити, а захваљујући нотификацији о прегледу постављеног документа, зна се тачно ко је све прегледао објављени садржај, а што се у сваком тренутку може употребити за евалуацију и процену ученичких активности. Нарочито је корисна датотека за постављање важнијих докумената, литературе и извора. Датотека би најпре морала имати Правопис. Упознавањем ученика са садржајем и областима овог приручника започињемо рад на групи, тим пре што је један од важних образовних задатака када је настава правописа у питању, обучавање и навикавање ученика на коришћење школског издања правописа. Поред Правописа, у датотеци постављамо списак ученика и табелу за праћење њихових активности, као и друга важна документа, нпр. друге релевантне приручнике, најуспелије ученичке радове, правописне занимљивости, одабране едукативне линкове и др. Опција догађаји је идеална за креирање позивница при чему се проверавају и понављају правила о употреби великог слова у писању личних имена, празника, наслова, заменице Ви из поштовања, писање датума и сл. Свака Фејсбук група има мени са више могућности за рад са фотографијама, при чему је могуће постављати своје фотографије, али и преузимати са интернета, разврставати их или креирати албуме. Опција белешке корисна је за постављање закључака, за складиштење и чување текстова. Коришћењем Фејсбук групе у образовне сврхе отвара се могућност боље комуникације како на релацији ученик-наставник, тако и ученици међусобно путем опције порука (чет), чиме се омогућава директно постављање питања и давања одговора. Питања и одговори могу се искористити за отклањање недоумица, пружања помоћи при учењу, али и за исправљање погрешки при писању порука. Добар начин комуникације је и имејл порука, при чему се ученици практично оспособљавају за исправно коришћење овог сервиса.

Трећи корак је планирање наставних активности и подразумева одабир градива који је погодан за увежбавање и обнављање, планирање динамике и начина рада. Предности употребе Фејсбука у настави су што захваљујући модерној технологији садржаји остају трајно забележени, па се ученици увек могу вратити на градиво које или нису добро савладали или су тада били одсутни. Када је гради- 
во из правописа у питању, не постоје посебна ограничења, што значи да се све наставне јединице могу успешно утврђивати, динамика рада зависи од степена савладаности одређене правописне области, од тога да ли се нека правописна област ради на часу или у виду домаћег задатка. Ако ученици имају за задатак да ураде неко правописно истраживање, ППт презентацију, индивидуални или групни пројекат, а за чију је реализацију ученицима потребно више времена, ти задаци могу бити на недељном, месечном или кварталном нивоу. Важно је истаћи да је у овој фази најважнији добар одабир едукационог материјала јер су они главни извор знања, на њима се заснива читав концепт овакве наставе, од правилног одабира примера зависи оствареност циљева и задатака модерне наставе. Приметно је да данас постоје разноразне групе и форуми који се баве правописним питањима и садржајима. Наставник може постављањем линкова ученике да упућује на блогове, групе, странице, али мора претходно да провери све те садржаје, јер постоје и оне групе код којих правописни садржај није на адекватан начин изложен. Управо због комплексности правописне проблематике правописом се све учесталије баве многи иако нису сви и стручни у тој области. (Прилог 2) На друштвеним мрежама последњих неколико година све је више угледних примера и креативних припрема за наставни час. Наставници данас све чешће користе друштвене мреже како би ученицима олакшали учење, подстакли дискусије о значају правилног изражавања на Фејсбуку и учинили им доступнијим корисне примере, видео материјале, презентације који могу бити од помоћи да се научено правописно градиво примени у пракси. Све је већи број оних наставника који сами креирају квалитетне блогове, групе, видео записе и друге садржаје и који су спремни да успеле примере поделе на друштвеној мрежи. Успешну примену друштвених мрежа, а у вези с наставом правописа запажамо у примерима: Правопас (http:// www.pravopas.rs/igra-izbor.php),Одељење учитеља Топлице

(https://uciteljtoplica.wordpress.com/\%D0\%B5\%D0\%B4\%D1\%83_2/ preuzmi-edu-sadrzaj), Отворени сервис образовања (http://oso.rs/), Знање није баук (http://srpski.in.rs/), База знања - Креативна школа (http://www.kreativnaskola.rs/bazaznanja/pretrazivanje.aspx) Дигитална школа (http://www.digitalnaskola.rs/) и сл. 
Четврти корак је евалуација и процена успешности примене Фејсбука у настави правописа. Један од најважнијих задатака школе, наставе и наставника је да подстиче развој својих ученика, прати и вреднује њихово напредовање. Праћење и оцењивање рада на групи је комплексно и обухвата широк дијапазон компонената. Оцењивање рада ученика у групи је у функцији повратне информације како за ученике тако и за наставника. Повратне информације условљавају даље планирање наставе, креирање нових активности, утичу на одабир правописних садржаја који ће бити обухваћени оваквом наставом. Будући да је циљ примене Фејсбука у настави правописа ефикасније учење и примена правописних правила, евалуација је моменат на основу ког се мења наставна пракса. Наставнику није примарни циљ да проверава знања својих ученика, већ да вреднује интересовање и мотивисаност ученика да унапређују своје вештине применом дигиталне хуманистике, да вреднују улагање напора и ентузијазам с којим ученик приступа раду, вољу да унапређује вештине писане комуникације.

Једна од бољих техника је формирање листе са именима ученика где наставник бележи све активности ученика, додељује или одузима поене за сваку успешну/неуспешну активност. Ученици на овај начин имају могућност да прате своје напредовање, али и да упоређују своја постигнућа са постигнућима осталих ученика. Како би се ученици мотивисали за самостално праћење сопственог рада, корисно је сачинити јединствени образац који би у почетним фазама оваквог рада ученицима помогао да рационално процењују своја постигнућа. (Прилог 3)

\section{2. Сценарио употребе Фејсбука у настави правописа}

Познато је да су писмени састави репрезентативни ученички радови где ученици треба да покажу највећи домет своје писмености. Како су „школски писмени задаци репрезентативни састави којима хоћемо да сагледамо какве ефекте даје укупна настава културе изражавања, а посебно настава писмености“ (Илић, 1998 ), на

тим часовима сви ученици имају задатак да напишу такав састав на 
коме ће показати и солидно познавање правописних правила. Задатак наставника је да ове радове пажљиво преглада, исправи, укаже на грешке и обавезно оцени. Колико је указивање на грешке важано, показује и податак да су за исправак писменог задатка обавезно предвиђена по два наставна часа. Међутим, у пракси се дешава да наставници ове часове користе за неке друге наставне активности, док се исправљање углавном своди на прецртавање ортоепских грешака и дописивање исправних облика, изостају и коректорски знаци, као и коментари иза рада. Ученици често и не знају где су погрешили, па је и исправка сведена на пуко преписивање писменог задатка.

У овом сценарију приказан је практичан пример рада Фејсбук групе, која је формирана и названа Правопис 8. разред. Група је затвореног типа чији су чланови 34 ученика 8. разреда. Све активности на групи су образовног карактера и односе се на правописну проблематику. Решење које ће бити приказано је пример из праксе који илуструје могућност да се Фејсбук успешно употреби на другом часу исправке писменог задатка, који је предвиђен за индивидуално исправљање радова.

Ученици имају задатак да користећи опције које нуди Фејсбук у неколико корака исправе свој писмени задатак. Како би се што боље припремио за овај час, одмах након прегледа писмених задатака, наставник одабира, скенира и поставља у виду фотографије само одабране одломке сваког задатка користећи опцију фотографије на групи. На маргинама прегледаног рада уписује коментаре којима се ученицима скреће пажња на погрешно примењено правописно правило. Колико ће опширан бити коментар, зависи од оцене јер задаци морају бити осмишљени тако да прате индивидуалне способности ученика, што значи да ће ученици са лошијом оценом из писмености добити детаљнија упутства, док се ученици са бољом оценом могу само упутити на одређену тачку у ПМС 2010.

Уводни део часа предвиђен је за договор о начину рада, методама, градиву и времену предвиђеном за израду. Будући да ученици већ знају коју су оцену добили, да бисмо их подстакли на активније учешће информишемо их и презентујемо им основни сценарио употребе Фејсбук групе на датом часу. Проблемски задатак решавају 
тако што проналазе и преузимају своје радове које је наставник претходно поставио са упутствима за исправку. Свим ученицима је дозвољено да се служе интернетом, датотеком, видео записима, текстуалним садржајима, могу поруком да затраже помоћ од другог ученика, пријатеља или наставника. Циљ је да ученици у договореном року исправе и објаве у групи предлог свог решења како би на крају могли да међусобно оцене и коментаришу предложена решења. Дискусијом и анализом решења процењујемо успешност ученичких радова. За ученике са одличном оценом осмишљени су другачији задаци, које могу и остали ученици да раде након дискусије или код куће. За овакав час предвиђено је да бољи ученици одаберу одломак из свог писменог задатка који на најбољи начин илуструје успешно примењено правописно правило и да користећи интересантан и једноставан алат ToonDoo ураде стрип. Упутство за коришћење овог алата ученици проналазе у датотеци, а уз мало маште могу да настану занимљиви радови. Када ученици заврше са израдом стрипа и у облачићима унесу жељени текст, потребно га је сачувати, именовати, унети краћи резиме, одабрати опцију да стрип буде јаван или не. Овај алат подржава могућност дељења и постављања на Фејсбук, тако да може бити доступан свим члановима групе. Стрип је образован и креативан начин да се ученици ангажују у настави јер пружа неограничене могућности за презентовање правописних правила.

Овакав начин рада ученицима је интересантан. Ученици на нов и креативан начин исправљају своје радове, имају могућност да користи различите алате како би се обновило заборављено градиво, али и могућност да у свако доба затраже помоћ.

\section{3. Методички модели и вежбе}

у функцији увежбавања правописних садржаја

За потребе наставе у којој ћемо Фејсбук групу користити у функцији увежбавања правописних садржаја, наставник се може определити да користи вежбе које имају елементе полупрограмираног материјала, а који се састоји од задатка, ученичке активности и повратне информације. Задатке које ученици добијају делују 
подстицајно на ученичке активности и усмеравају их на истраживање и сарадњу приликом решавања, при чему је поред формалног учења на часу или у делу часа, омогућено неформално учење, могућност избора да се задаци раде код куће без временског ограничења. Повратна информација пружа се након обављеног задатка.

\section{Задатак 6р. 1}

\section{Користимо Правопис}

Дешава се да имамо недоумице о томе како се нека реч пише и зато је важно да знамо где можемо пронаћи одговор. У овој вежби обучавамо се и навикавамо на коришћење Правописа 2010. Упознај се са садржајем овог приручника, па одговори на питања: Из колико се делова састоји? Које области обрађује? Шта представља словна, а шта бројевна ознака у основном делу приручника? Објасни улогу другог дела приручника?

Активност: Будући да је Правопис 2010 постављен у датотеци, приручник је доступан свим ученицима који индивидуално или у пару истражују и одговарају на питања. Током рада откривамо предности дигиталног издања овог приручника, као што је могућност коришћења пречица које олакшавају рад или зумирање жељене странице.

Повратна информација: Приручник се састоји из два главна дела: Правила и њихови основи, и Речник уз Правопис. Да бисмо подигли ниво писмености морамо да познајемо правописна правила, која су изложена у правописном приручнику. Поступак руковања овим приручником подразумева да се најпре консултује речник, а у основном тексту можемо пронаћи одговоре на она питања која нас интересују.

Овај задатак можемо решавати како на часовима редовне, тако и на часовима додатне наставе, за време ваннаставних активности, али и у виду домаћих задатака. Могућности су неограничене и када су правописни садржаји у питању, наставник се може определити само за једну област, на пример за правила о скраћивању речи, спојеним и одвојеним писањем изабраних речи, изузецима од неког правила итд. 


\section{Задатак 6р. 2}

\section{Тражимо правописне грешке ван простора интернета}

У овој вежби будите детектив и трагајте за информацијама о примени правописа у вашој околини. проверите да ли су наслови, огласи, рекламе исправно написане. Усликајте и објавите фотографију тако да је могу видети само чланови групе Правопис 8. разред.

Активност: Ученици постављају фотографије и у тренутку када је постављена на Фејсбуку свим члановима групе стиже нотификација не само о новој објави, већ и члановима који су поруку видели. Коришћењем алата маркирају се грешке и дописују исправни нормирани облици у складу са Правописом 2010. Ученици који желе да брже напредују могу уз исправно написану реч да упишу и бројевну и словну ознаку која нас упућују на одговарајуће правописно правило.

Повратна информација: Користећи Правопис 2010, проверавамо да ли су приложени примери коректно одрађени, од успелих примера правимо заједнички албум који се налази у опцији фотографије. У зависности од квалитета урађеног и уложеног труда ученици ће добити поене које уносимо у формирану листу која је постављена у датотеци.

\section{Задатак бр. 3}

\section{Тражимо правописне грешке на интернету}

У овој вежби одаберите неког вршњака са којим сте се дописивали. Можете ли да се сетите које правописне грешке прави? Да ли су те грешке настале нехотице или из незнања? Потом одаберите неког старијег и примените исти поступак. На крају размислите о себи и о свом изражавању.

Активност: Ученици имају више могућности да ураде овај задатак, могу да провере поруке пријатеља, неког старијег, али и своје. Опредељују се за три грешке, које коментаришу уз навођење исправног решења. Ученици могу готове радове послати поруком наставнику или поделити на зид.

Повратна информација: Све грешке које су ученици издвојили и предлог исправног облика упоредити са речју у правописном речни- 
ку или у Речнику српскога језика Матице српске. На основу анализе радова уочавамо типичне грешке.

\section{Задатак бр. 4 Креирај текст}

а) Одабери неку од понуђених апликација (стикера) и на основу слике напиши краћи текст користећи сва три модела управног говора; б) одабери једну интернет скраћеницу (нпр. втп, нп, нни, нзм, бзв) и бар један емотикон које ћеш исказати реченицом.

Активности: Коришћењем технолошких иновација, решавање овог задатка подразумева превођење неформалне комуникације у формалну, при чему ученици имају потпуну слободу да креативно и духовито осмишљавају реченице које ће бити написане у складу с правописном нормом.

Повратна информација: Данашњи ученици све чешће у међусобној, неформалној комуникацији користе апликације, емотиконе и скраћенице да изразе своја осећања, мисли и расположења према некој особи. Неке скраћенице су универзалне јер је њихово значење опште познато, али је све више оних које су неупућенима неразумљиве. Ученички радови показаће у којој мери су савладана правописна правила у вези са управним говором, интерпункцијским знацима и писањем речце не, а повратна информација зависи од успешне/неуспешне примене ових правила.

\section{4. Рефлексија правописних вежби}

Пожељно је да подучавање и усмеравање ученика да Фејсбук користе у образовне сврхе у настави правописа започнемо вежбама које подразумевају коришћење Правописа српскога језика јер је то по правилу „обавезна књига за ученике у старијим разредима основне школе“ (Брборић 2011: 101). На жалост, већина ученика старијих разреда нема овај приручник, па би оваква вежба била идеална прилика да се сви ученици упознају и стекну навику да користе Правопис. Када се ученици упознају са садржајем ове књиге, наставник може 
одабрати и неки други методички модел модел, на пример програмирану или полупрограмирану наставу. Ученике који покажу веће интересовање, воље и труда за овакав начин рада, можемо упутити и на друге приручнике и додатну литературу.

Други и трећи задатак омогућавају ученицима да постепеним прикупљањем информација усвоје нови начин понашања који ће касније применити у пракси. Истраживањем правописних грешака у окружењу, својих и правописних способности вршњака, ученици подижу ниво своје писмености. Уз помоћ наставника откривају које су грешке учесталије, које настају из незнања, а које нехотично. Проблем писања интерпункције, грешке приликом састављеног или одвојеног писања речи, писање гласа $j$, настају из незнања. Погрешна употреба великог слова правда се жељом да се успостави бржа комуникација, али и чињеницом да при писању захтевају употребу два тастера. Ипак, ове грешке нису баш увек нехотичне.

Најинтересантнији је четврти задатак. У њему се, као што се из примера види, огледа тенденција да се говорни језик приближи писаном постајући на тај начин „трећи медијум који развија своја системска правила“ (Кристал 2001: 48). Истражујући језик друштвених мрежа Кристал не мисли да је онлајн комуникација неписмена, већ сматра да новостворени модели типа апликације, емотикони и новоформиране скраћенице могу да обогате језик. Чињеница је да се на Фејсбуку често комбинују речи и слике, што је и разумљиво јер су они у неку руку модерна верзија ребуса и као такви могу се успешно користити за примену правописних правила.

\section{4. Закључак}

Наставници српског језика добро знају да је сваки живи језик подложан променама. Свака нова генерација ученика успоставља неке своје комуникацијске системе, а који су нарочито изражени на друштвеним мрежама, где је комуникација између писца и примаоца поруке специфична будући да написано на екрану није исто као написано на папиру. Кроз примере из свакодневног језика на Фејсбуку, где 
се на први поглед највише крше правописне норме, ученици могу да науче и боље разумеју основна правописна правила и улогу језичких норми, као и да негују културније изражавање.

Настава правописа која је подржана средствима дигиталне хуманистике омогућава истовремено и стицање и практичну примену знања ученика. Суштина је да ученик сам може да одређује темпо рада, да бира садржаје који му највише одговарају, да тражи и проналази додатне информације, користећи модерну технологију, при чему има могућност да се у свако доба врати на исти садржај. Ученицима се не пружају готова знања, већ се корак по корак усмеравају да Фејсбук користе и у образовне сврхе, а не само за забаву. У овом раду намера нам је била да покажемо како се Фејсбук може применити у настави правописа што не значи да друштвене мреже треба по сваку цену примењивати на сваком наставном часу. Према томе, не само да није добро претеривати са применом иновативне технологије, већ постоје правописни садржаји који се врло успешно могу применити традиционалним поступцима и методама. С друге стране, на Фејсбуку се готово свакодневно појављују Фејсбук профили, групе и странице које се баве правописом, објашњавају правописна правила, нуде помоћ пре свега ученицима, међу којима има и корисних садржаја, али и злоупотребе, мноштво погрешних информација, лаичког тумачења правописних правила. У том смислу пожељно је да наставник српског језика скрене пажњу својим ученицима на штетност таквих садржаја и спречи да се њихова правописна уверења заснивају на погрешним информацијама.

\section{Литература}

Aypay, A., Erdogan, M., \& Sozer, M. A. (2007). Variation among schools on classroom practices in science based on TIMSS-1999 in Turkey. Journal of Research in Science Teaching, 44(10), 1417-1435.

Богданић 2013: Александар Богданић, Англицизација кроз медијско комуницирање и превођење: утицај енглеског на српски у вријеме медијатизације, у Радови филозофског факултета, бр. 16, књига 1/1, Пале.

Брборић 2011: Вељко Брборић, Правопис и школа, Београд, Чигоја.

Влајковић 2010: Ивана Влајловић, Утицаји енглеског језика на српски на плану 
правописа, лексике и граматике у комуникацији на Фејсбуку. Комуникација и култура онлајн I (1): 183-196.

Вучковић 1993: Мирољуб Вучковић, Методика наставе српског језика и књижевности у млађим разредима основне школе; за студенте педагошке академије, треће, преуређено издање, Београд, Завод за уџбенике и наставна средства.

Дурбаба 2009: Оливера Дурбаба, Феномен „парландо“ и лингвистички статус интернет форума. у: Српски језик у употреби, приредили Слободан Штетић и остали, 447-57. Крагујевац: Филолошко-уметнички факултет.

Илић 1998: Павле Илић, Српски језик и књижевност у наставној теорији и пракси, y: Методика наставе, друго прерађено и допуњено издање, Нови Сад, Змај.

Junco 2010: R. Junco, D. Merson, \& D. W. Salter, The effect of gender, ethnicity, and income on college students' use of communication technologies. CyberPsychology, Behavior, and Social Networking, 13(6), 37-53. (приступљено 24.8.2015)

Junco 2013: R. Junco, Comparing actual and self-reported measures of Facebook use. Computers in Human Behavior, 29(3), 626-631. (приступљено 24.8.2015)

Кастелс 2009: Мануел Кастелс, Моћ комуникација, Београд, Мултимедиа Клио.

Петровић 2013: Далибор Петровић, Друштвеност у доба интернета, Нови Сад: Академска књига

Правопис 2010: Правопис српскога језика (измењено и допуњено издање), приредили: Митар Пешикан, Јован Јерковић, Мато Пижурица; редакција измењеног и допуњеног издања: Мато Пижурица (главни редактор), Милорад Дешић, Бранислав Остојић, Живојин Станојчић, Нови Сад, Матица српска

Правилник о наставном плану за други циклус основног образовања и васпитања и наставном програму за седми и осми разред основног образовања и васпитања (2013), Просветни гласник, 1/2013 и 4/2013.

Прћић 2005: Т. Прћић, Енглески у српском, Нови Сад, Змај.

Casey 2011: G. Casey, T. Evans, Designing for Learning: Online Social Networks as a Classroom Environment, Vol 12, No 7, 1 - 26. (приступљено 24.8.2015)

Crystal 2001: David Crystal, A language revolution: From reluctance to renaissance. http://davidcrystal.com/DC_articles/Langdeath8.pdf (приступљено 24.8.2015)

\section{Прилог 1}

\section{Анкета за испитивање ставова ученика о учењу на друштвеним мрежама}

1. Да ли имате профил на друштвеној мрежи?

а) Фејсбук; б) Твитер; в) гугл+; г) ЛинкедИн; д) Остале; ђ) Немам 
2. Колико времена проводите на друштвеним мрежама?

а) стално сам улогован(а); б) 1 сат дневно; в) 2 сата дневно; г) 4 сата дневно; д) једном недељно; ђ) остало.

3. Који су разлози коришћења?

а) дописивање; б) пратим статусе пријатеља; в) постављам статусе и фотографије; г) играње игрица.

4. Да ли се може учити помоћу друштвених мрежа?

а) да; б) не; в) не знам.

(Ако је одговор негативан, укратко образложи!)

5. Да ли би волео(ла) да користиш друштвене мреже у настави?

а) да; б) не; в) нисам сигуран/сигурна.

(Ако је одговор негативан, укратко образложи!)

\section{Прилог 2}

\section{Корисни линкови}

http://www.pravopas.rs/igra-izbor.php https://uciteljtoplica.wordpress.com/\%D0\%B5\%D0\% B4\% D1\%83_2/preuzmi-edu-sadrzaj

http://oso.rs/

http://srpski.in.rs/

http://www.kreativnaskola.rs/bazaznanja/pretrazivanje.aspx

http://www.digitalnaskola.rs/

https://www.facebook.com/groups/438742336268992/ Правопис и граматика српског језика (група)

https://www.facebook.com/groups/120548667961603/ Правопис и граматика српског језика затворена група)

https://www.facebook.com/pages/Pravopis/79739156288Правопис (непрофитна организација) https://sr-rs.facebook.com/opismenise страница

https://www.facebook.com/pravopis111 заједница Дневна доза правописа (фотографије)

https://www.facebook.com/Pravopisbezmuke Pravopis bez muke namenjen je najširoj javnoj upotrebi u prevevazilaženju pravopisnih nedoumica.

https://www.facebook.com/pages/Pravopisneve\%C5\%BEbe/117248611722616?ref=br _s Pravopisne vežbe Веб-страница за културу/друштво

https://www.facebook.com/groups/1423287217931212/ Правопис за све! затворена група

https://www.facebook.com/groups/207073442636877/ Правописне заврзламе јавна група 
https://www.facebook.com/groups/307092875968242/ Српски језик- правопис и граматика (јавна група)

https://www.facebook.com/groups/234819916644997/ Правописне заврзламе (јавна група)

https://www.facebook.com/profile.php?id=100009279221671\&sk=friends Правопис Правопис

\section{Прилог 3}

\section{Самопроцена}

- За сваку вашу објаву у оквиру задатка забележите себи 2 поена (доказ: објава на зиду);

- За додатни правописни садржај који сте поделили додајте себи још 1 поен (доказ: објава на зиду);

- Прелистајте поруке које сте послали у протеклом периоду, за сваку уочену и исправљену грешку додајте по 1 поен (доказ: снимљена грешка и дописана исправка);

- За свако коришћење Правописа по 2 поена (доказ: позивање на извор);

- Ако сте помогли некоме, додајте 1 поен (доказ: коментар);

- Ако нисте извршили месечни задатак одузмите себи 5 поена. На крају месеца убележи резултат и процени свој рад:

Кључ:

Испод 7 поена - пробуди се!

8 - 10 - Можеш боље!

11 - 14 - Добар рад!

15 - 17 - Врло добро!

18 - 20 - Буди поносан на знање које си постигао(ла)! 
Ученички радови
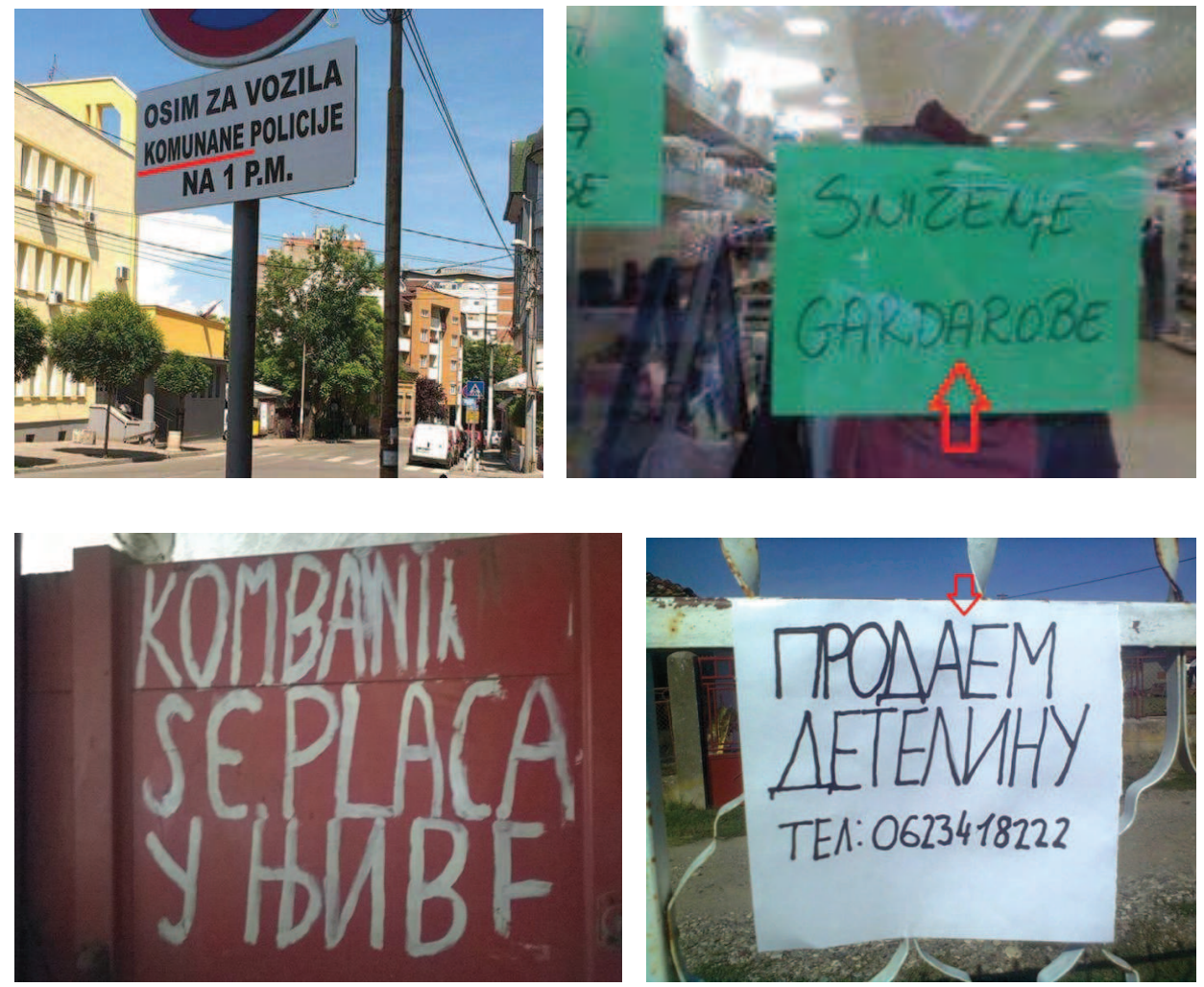


\author{
Cica Bacic \\ Primary School "Žabare" \\ Krusevac
}

\title{
SOCIAL NETWORKS USE IN THE TEACHING OF SERBIAN LANGUAGE FOR THE ORTHOGRAPHY DOMAIN
}

\begin{abstract}
Summary
In this work we will consider possibilities of the use of social networks in teaching of Serbian language, especially in the instructional domain of orthography. The role of the social networks, mainly Facebook, in the everyday life of our students is considerable. Students have their Facebook profiles in the fourth grade already, which are being used mostly for fun, games and peer to peer communication. Possibilities this social network is offering are endless and can be successfully used during the teaching process. Students can use Facebook in educational purposes, during class, and after classes, for homework. With our didactical and methodical approach in which we will include choosing of facts, tools and procedures, we will allow to the students to use the resources of the digital humanity for reaching the target - more effective written and spoken expression, critical and creative thinking. In the conditions of learning in a village school, we will enable our students to replace the lack of the learning tools and books with the positive use of the social networks. With an interdisciplinary work and correlation with other subjects we will include demonstrative methods in the learning process, and students will be able to solve orthographical problems, to communicate, to carry out their own researches, to manage their time, to work individually or practice team work, to tolerate dissimilarities and different opinions, to grow their confidence. This way of learning makes schoolwork more modern and that is an advantage over the traditional teaching. In this work we will introduce a couple of examples from our own teaching practice which were successful and applicable in the everyday teaching practice and which include the use of available and easily reachable resources
\end{abstract}

Key words: social networks, orthography, Facebook, written and spoken expression, teaching tools, correlation, modern teaching 